
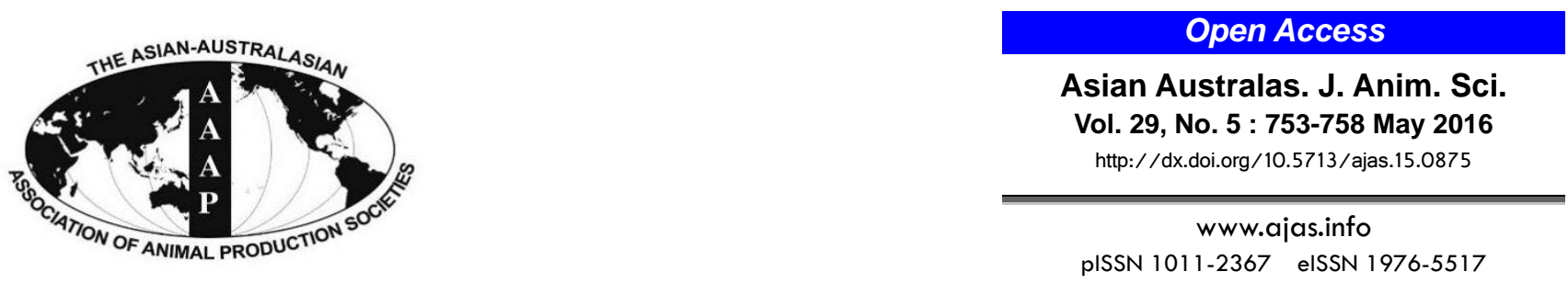

\title{
Evaluation of Optimum Moisture Content for Composting of Beef Manure and Bedding Material Mixtures Using Oxygen Uptake Measurement
}

\author{
Eunjong Kim, Dong-Hyun Lee ${ }^{1}$, Seunggun Won ${ }^{2}$, and Heekwon Ahn* \\ Department of Animal Biosystems Science, Chungnam National University, Daejeon 305-764, Korea
}

\begin{abstract}
Moisture content influences physiological characteristics of microbes and physical structure of solid matrices during composting of animal manure. If moisture content is maintained at a proper level, aerobic microorganisms show more active oxygen consumption during composting due to increased microbial activity. In this study, optimum moisture levels for composting of two bedding materials (sawdust, rice hull) and two different mixtures of bedding and beef manure (BS, Beef cattle manure+sawdust; BR, Beef cattle manure+rice hull) were determined based on oxygen uptake rate measured by a pressure sensor method. A broad range of oxygen uptake rates ( 0.3 to $33.3 \mathrm{mg} \mathrm{O} / \mathrm{g}$ VS d) were monitored as a function of moisture level and composting feedstock type. The maximum oxygen consumption of each material was observed near the saturated condition, which ranged from $75 \%$ to $98 \%$ of water holding capacity. The optimum moisture content of BS and BR were 70\% and 57\% on a wet basis, respectively. Although BS's optimum moisture content was near saturated state, its free air space kept a favorable level (above 30\%) for aerobic composting due to the sawdust's coarse particle size and bulking effect. (Key Words: Moisture Content, Beef Manure, Bedding Material, Oxygen Uptake Rate, Water Holding Capacity)
\end{abstract}

\section{INTRODUCTION}

An estimated 46.5 million tones of animal manure was produced from Korean livestock industry in 2011, and the amount of animal manure produced is increasing every year. Especially, annual production of manure from cattle is estimated to be 20 million tons, which is equivalent to $44 \%$ of the total animal manure production in Korea. The cattle manure is generally collected by using bedding materials such as sawdust and rice hull in Korea, thus composting is the most common treatment method of collected cattle manure and bedding material mixtures. More than $95 \%$ of the cattle manure produced in Korea is treated using a composting process (Ahn et al., 2011).

In order to utilize treated cattle manure properly as

\footnotetext{
* Corresponding Author: Heekown Ahn. Tel: +82-42-821-5785, Fax: +82-42-823-2766, E-mail: hkahn@cnu.ac.kr

${ }^{1}$ Animal Environment Division, National Institute of Animal Science, Jeonju 55365, Korea.

2 Department of Animal Resources, College of Life \& Environmental Sciences, Daegu University, Daegu 38453, Korea. Submitted Oct. 22, 2015; Revised Nov. 16, 2015; Accepted Nov. 21, 2015
}

fertilizer or recycled bedding material, biological stabilization of nutrients and organic materials should be accomplished appropriately. Composting performance is influenced by various factors such as moisture content, aeration, temperature, $\mathrm{pH}$, carbon to nitrogen ratio $(\mathrm{C} / \mathrm{N})$, bulk density and free air space (FAS). Among those variables, moisture content is considered as one of the key parameters affecting biodegradation process. Many previous studies have suggested proper moisture content to achieve successful composting operation. Haug (1993) recommended maintaining composting pile moisture content between $40 \%$ and $60 \%$. Low moisture content (below $40 \%$ ) limits microbial activity. On the other hand, very high moisture triggers anaerobic conditions because the pore spaces of solid matrices are filled with water rather than air (de Bertoldi et al., 1983; Das and Keener, 1997). However, some studies reported different optimum moisture levels for leading successful composting. Liang et al. (2003) recommended $50 \%$ moisture content as the minimal requirement for obtaining adequate microbial activities. Ahn et al. (2008b) suggested that the optimum moisture content of highly stabilized soil compost blend is around 
$25 \%$ (wet basis [wb]). This wide range of optimum moisture content reported by previous studies means that there is no generally applicable optimal moisture level for diverse composting materials.

Murwira et al. (1990) used water holding capacity (WHC) to evaluate the moisture content influence on the manure decomposition rate. WHC refers to the amount of water held in the composting materials which is available for microorganisms. WHC is influenced by the organic matter content, texture, structure of composting materials. Compost ingredients have their own unique characteristics affecting WHC. Ahn et al. (2008b) suggested optimum moisture levels for a variety of composting materials based on WHC concept and proved that the optimum moisture content of each material is near its saturated condition. WHC is the more definite indicator than aforementioned simple moisture content to describe optimum moisture content of diverse composting materials. This study thus determined optimum moisture content by testing respiration rate at different controlled moisture levels based on WHC.

Few studies have been conducted on determining optimal moisture content of composting materials using microbial respiration activity (Ahn et al., 2008b). The microbial respiration activity is commonly evaluated based on oxygen uptake and carbon dioxide production. Respiration activity tests can be classified into two major methods: the static and dynamic ones (Komilis and Kanellos, 2012). The static respiration test is the method to evaluate $\mathrm{O}_{2}$ uptake by measuring pressure differences or direct $\mathrm{O}_{2}$ content in the headspace (Gea et al., 2004; Adani et al., 2006; Ruggieri et al., 2008; Wagland et al., 2009; Ponsá et al., 2009; 2010; Komilis et al., 2011). Whereas, dynamic respiration test (DRT) is the method to measure the airflow rate and $\mathrm{O}_{2}$ contents at the inlet and outlet of the system equipped with continuous aeration device (Gea et al., 2004; Adani et al., 2006; Barrena-Gómez et al., 2005;2006; Tremier et al., 2005; Komilis and Tziouvaras, 2009; Wagland et al., 2009; Ponsá et al., 2010). Although DRT is a more realistic method to represent respiration activity during composting process, it is not easy to measure airflow and $\mathrm{O}_{2}$ contents of introduced and exhausted air accurately. Thus, in this study, SRT method was selected in order to increase oxygen uptake measurement accuracy and test many samples at once.

Although considerable research has been conducted to determine optimal moisture content of various compost materials, there are a limited number of reports on beef manure collected from traditional bedded pack barn in Korea. For this reason, optimum moisture content for composting of bedding and beef cattle manure mixtures collected from bedded pack barn was evaluated using respiration method.

\section{MATERIALS AND METHODS}

\section{Beef manure and bedding material mixtures}

Bedding material (sawdust or rice hull) and beef cattle manure mixtures were collected from a bedded pack barn in Korean National Institute of Animal Science beef farms. About 3 months after placing fresh bedding material on the floor, all mixtures of bedding and beef manure were removed from barn. All samples were collected and stored in 4 degree Celsius refrigerator until being used.

\section{Moisture content and volatile solids}

Moisture content was determined by drying moistened samples at $105^{\circ} \mathrm{C}$ for approximately 24 hours. Volatile solids were measured by combustion at $550^{\circ} \mathrm{C}$ in a muffle furnace for 8 hours (USCC, 2002).

\section{Water holding capacity}

WHC was measured by a modified Hilgard method (Mabuhay et al., 2003; Ahn et al., 2008b). A wet sample with known moisture content was weighed $\left(\mathrm{W}_{\mathrm{i}}: \mathrm{g}\right.$, wb) and soaked in the water for 1 day. The soaked sample was drained through Watman \#2 filter paper overnight inside of a plastic chamber to prevent loss of water due to evaporation (Figure 1). The saturated sample was weighed $\left(\mathrm{W}_{\mathrm{s}}\right.$ : $\mathrm{g}$, wb) to find out the soaked condition. The WHC was determined according to the following equation (Glanville et al., 2013):

$$
\mathrm{WHC}(\%)=\frac{\left\{\left(\mathrm{W}_{\mathrm{S}}-\mathrm{W}_{\mathrm{i}}\right)+\mathrm{MC}_{\mathrm{i}} \times \mathrm{M}\right\}}{\mathrm{W}_{\mathrm{s}}} \times 100
$$

Where $\mathrm{MC}_{\mathrm{i}}$ is the initial moisture content of sample (decimal) and $\mathrm{M}$ is mass of the wet sample.

\section{Free air space}

Free air space of compost materials was calculated by

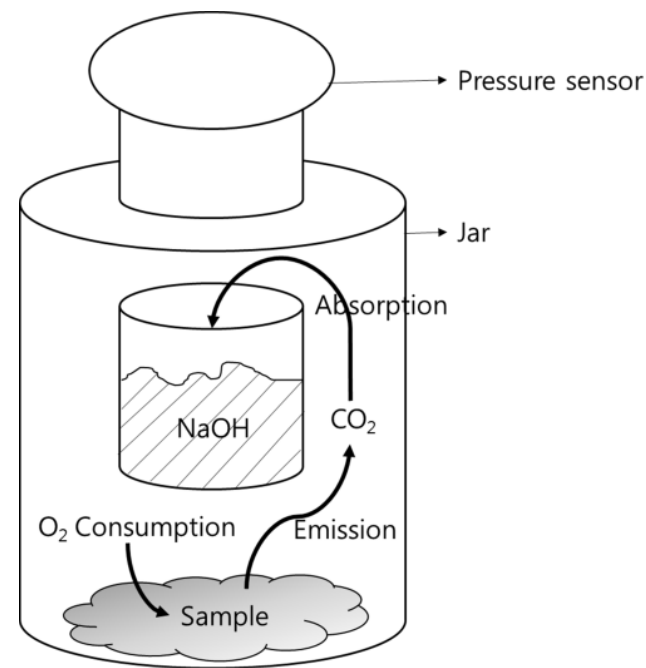

Figure 1. Schematic diagram of pressure measurement apparatus. 
the following equation reported by Ahn et al. (2009).

$$
\mathrm{FAS}=1-\mathrm{P}_{\mathrm{wb}} \cdot\left(\frac{\mathrm{MC}}{\mathrm{P}_{\mathrm{w}}}+\frac{\mathrm{DM} \cdot \mathrm{vS}}{\mathrm{P}_{\mathrm{vs}}}+\frac{\mathrm{DM} \cdot(1-\mathrm{vS})}{\mathrm{P}_{\mathrm{ash}}}\right)
$$

Where MC is moisture content (decimal, wb), VS is organic matter (decimal, dry basis [db]), DM is dry matter (decimal, wb), $\mathbf{P}_{w b}$ is wet bulk density of sample $\left(\mathrm{kg} / \mathrm{m}^{3}\right)$, $\mathrm{P}_{\mathrm{w}}$ is density of water $\left(1,000 \mathrm{~kg} / \mathrm{m}^{3}\right), \mathbf{P}_{\mathrm{vs}}$ is density of organic material $\left(1,600 \mathrm{~kg} / \mathrm{m}^{3}\right)$, and $\mathbf{P}_{\text {ash }}$ is density of inorganic material $\left(2,500 \mathrm{~kg} / \mathrm{m}^{3}\right)$ (Rahman, 1995; Van Ginkel et al., 1999; Richard et al., 2002; Ahn et al., 2008a; 2009).

\section{Respiration test}

The influence of moisture content on microbial activity was evaluated based on respiration rate using a pressure sensor method (OxiTop system, Sadaka et al., 2004; Ahn et al., 2008b). The respiration rate of each composting material was measured at six different moisture levels (30\%, $45 \%, 60 \%, 75 \%, 90 \%$, and $98 \%$ of WHC). Each collected sample was dried at $30^{\circ} \mathrm{C}$ for 1 to 2 day, and then the calculated amount of water was added to adjust moisture levels set based on percentage of the WHC. The OxiTop system was composed of a $1 \mathrm{~L}$ volume jar, a pressure sensor head with data-logging function (OxiTop-C WTW, Weiheim, Germany), and a plastic cup for $\mathrm{NaOH}$ solution (Figure 1). As oxygen is consumed by microorganism, pressure drop occurs because generated $\mathrm{CO}_{2}$ is absorbed into the $\mathrm{NaOH}$ solution. About $10 \mathrm{~g}$ of moisture adjusted samples and plastic cup with $40 \mathrm{~mL}$ of $1 \mathrm{M} \mathrm{NaOH}$ solution was placed in the $1 \mathrm{~L}$ volume jar. Tightly sealed jars with samples and $\mathrm{NaOH}$ solution were incubated at $30^{\circ} \mathrm{C}$ for 2 days. All measurements were done in triplicate. The oxygen consumption was determined according to the following equation (Ahn et al., 2008b):

$$
\begin{aligned}
& \mathrm{O}_{2}\left(\frac{\mathrm{mg}}{\mathrm{g}_{\mathrm{vs}}} \mathrm{d}\right) \\
& =\frac{\Delta P(h P a) \times 100\left(\frac{P a}{h P a}\right) \times 1\left(\frac{N}{\mathrm{~m}^{3}}\right) \times V\left(\mathrm{~m}^{3}\right) \times 32\left(\frac{\mathrm{g}}{\mathrm{mole}}\right) \times 1,000\left(\frac{\mathrm{mg}}{\mathrm{g}}\right)}{8.314\left(\frac{1}{\text { mole.K }}\right) \times 1\left(\frac{\mathrm{N} \cdot \mathrm{m}}{\mathrm{J}}\right) \times T(\mathrm{~K}) \times \frac{t(h)}{24\left(\frac{h}{d}\right)} \times \mathrm{W}(\mathrm{g}) \times(1-\mathrm{MC}) \times \mathrm{VS}_{\text {decimal }}}
\end{aligned}
$$

Where $\mathrm{O}_{2}$ is the oxygen consumption $\left(\mathrm{mg} / \mathrm{g}_{\mathrm{vs}} \mathrm{d}\right) ; \Delta P$ is the gap between the maximum and final pressure $(\mathrm{hPa}), V$ is the jar volume $\left(\mathrm{m}^{3}\right), \mathrm{T}$ is the incubation temperature $\left({ }^{\circ} \mathrm{K}\right), t$ is the incubation time $(\mathrm{h}), \mathrm{W}$ is the weight of sample $(\mathrm{g})$.

\section{RESULTS AND DISCUSSION}

\section{General characteristic of bedding materials and beef manure mixtures}

The moisture content, volatile solids, $\mathrm{C} / \mathrm{N}$, bulk density, and WHC of 2 bedding materials and 2 different mixtures of bedding and beef manure are shown in Table 1 . The volatile solids content of sawdust and rice hull were $99 \%$ and $86 \%$, respectively. Rice hull has less volatile solids content than sawdust because it generally contains $13 \%$ to $29 \%(\mathrm{db})$ inorganic materials mainly composed of Silicon dioxide (Okutani, 2009). The WHC of sawdust and rice hull were $6.0 \pm 0.9 \mathrm{~g} \cdot$ water/g.DM and $1.7 \pm 0.2 \mathrm{~g} \cdot$ water/g.DM, respectively. Due to its high Silicon dioxide content, WHC of rice hull is relatively lower than sawdust.

\section{Optimum moisture content}

Liang et al. (2003) suggested that moisture content has a greater influence on microbial activity than temperature. Previous studies have suggested wide range of optimum moisture contents (25\% to $80 \%)$ for successful animal manure composting (Jeris and Regan, 1973; Tamura and Osada, 2006; Zhu, 2006; Li et al., 2008). This wide range of optimum moisture content reported by previous studies implies that there is no commonly applicable optimal moisture level for various composting materials.

Since optimum moisture content ranges widely depends on physical, chemical, and biological characteristics of feedstock, optimum moisture content should be determined for a specific target material. Oxygen uptake rates of sawdust and rice hull bedding materials as functions of moisture are illustrated in Figure 2. Sawdust showed the maximum oxygen uptake rate when its moisture content was $75 \%$ of WHC, while rice hull reached to a peak when it was $98 \%$ of WHC. The maximum oxygen uptake rate of rice hull (7.43 $\left.\mathrm{mg} \mathrm{O} \mathrm{O}_{2} / \mathrm{g}_{\mathrm{vs}}-\mathrm{d}\right)$ was twice the peak oxygen uptake rate of sawdust (3.52 $\mathrm{mg} \mathrm{O}_{2} / \mathrm{g}_{\mathrm{vs}}-\mathrm{d}$ ) because an easily biodegradable material like rice flour attached to rice hull during rice polishing process may contribute to increase oxygen uptake rate of rice hull.

Table 1. General characteristics of bedding and beef manure mixtures

\begin{tabular}{lccccc}
\hline & Moisture content $(\%, \mathrm{wb})$ & Volatile solids $(\%, \mathrm{db})$ & C/N ratio & Bulk density $\left(\mathrm{kg} / \mathrm{m}^{3}\right)$ & WHC $(\mathrm{g} \mathrm{water} / \mathrm{g} \mathrm{DM})$ \\
\hline Sawdust & $25.1 \pm 0.61$ & $99.2 \pm 0.04$ & 104.6 & $149.3 \pm 4.61$ & $6.0 \pm 0.86$ \\
Rice hull & $11.2 \pm 0.04$ & $85.7 \pm 0.05$ & 95.2 & $97.2 \pm 3.27$ & $1.7 \pm 0.2$ \\
$\mathrm{BS}^{1}$ & $68.7 \pm 0.38$ & $82.1 \pm 0.07$ & 21.8 & $658.2 \pm 11.53$ & $3.7 \pm 0.79$ \\
BR $^{2}$ & $17.2 \pm 0.65$ & $80.6 \pm 0.19$ & 18.3 & $260.0 \pm 0.53$ & $2.8 \pm 0.74$ \\
\hline
\end{tabular}

wb, wet basis; db, dry basis; C/N, carbon to nitrogen ratio; WHC, water holding capacity; DM, dry matter.

Mean \pm standard error, $\mathrm{n}=3$.

${ }^{1} \mathrm{BS}$, beef cattle manure and sawdust mixture. ${ }^{2} \mathrm{BR}$, beef cattle manure and rice hull mixture. 


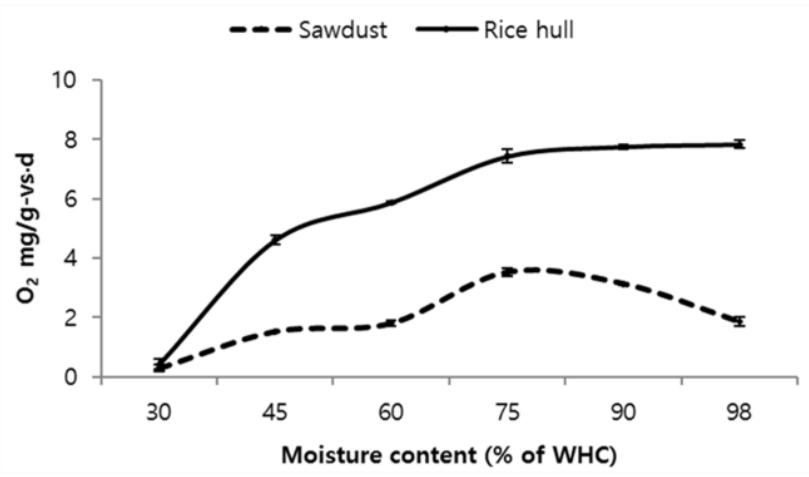

Figure 2. Oxygen uptake rates of sawdust and rice hull as functions of moisture. The error bars give the sample standard deviation between three replicated tests.

Oxygen uptake rates of beef cattle manure+sawdust (BS) and beef cattle manure+rice hull (BR) as functions of moisture are shown in Figure 3. The maximum oxygen consumption of each material was monitored near saturated condition, which ranged from $75 \%$ to $90 \%$ of WHC. The maximum oxygen uptake rate of $\mathrm{BR}\left(33.3 \mathrm{mg} \mathrm{O} / \mathrm{O}_{\mathrm{vs}}-\mathrm{d}\right)$ was almost double the maximum oxygen uptake rate of BS (13.2 $\left.\mathrm{mg} \mathrm{O} / \mathrm{g}_{\mathrm{vs}}-\mathrm{d}\right)$.

The optimum moisture contents of BS and BR based on respiration test were $70 \%$ and $57 \%$ (wb), respectively (Table 2). Even if optimum moisture content of BS was near saturated state $(90 \%$ of WHC), its FAS maintained favorable level, above $30 \%$, for aerobic composting (Külcü and Yaldiz, 2014).

\section{Energy generated through biodegradation}

Energy produced through organic material degradation is proportional to the quantity of volatile solids degraded and the amount of oxygen consumed. With a greater oxygen uptake observed when moisture content was near the optimum level, the energy generated through volatile solids degradation under optimum moisture conditions was also anticipated to be greater than under inappropriate moisture conditions. Haug (1993) suggested that $13.6 \mathrm{~kJ}$ of energy

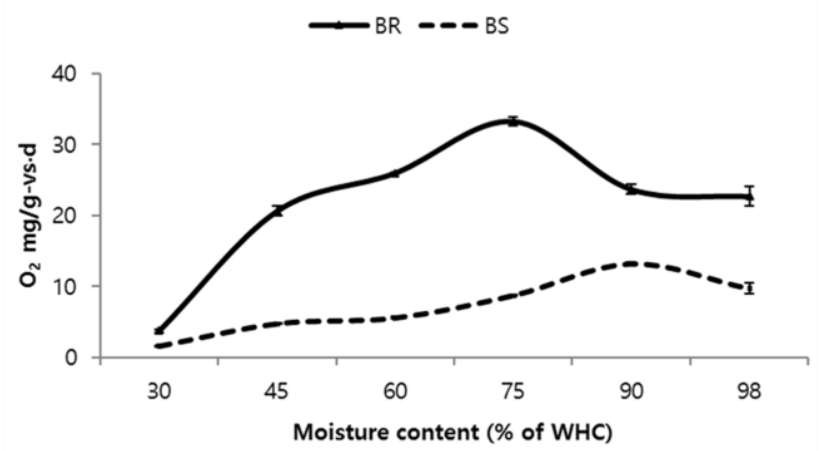

Figure 3. Oxygen uptake rates of bedding and beef manure mixtures as functions of moisture. The error bars give the sample standard deviation between three replicated tests.
Table 2. Percentage of water holding capacity, moisture content, and free air space of samples when maximum oxygen consumption was observed

\begin{tabular}{lccc}
\hline & \% of WHC & MC $(\%, w b)$ & FAS $(\%)$ \\
\hline Sawdust & 75 & $64.7 \pm 0.16$ & $73.0 \pm 0.02$ \\
rice hull & 98 & $61.0 \pm 3.15$ & $78.7 \pm 0.04$ \\
BS $^{1}$ & 90 & $69.7 \pm 0.07$ & $44.7 \pm 0.05$ \\
BR $^{2}$ & 75 & $57.3 \pm 0.27$ & $59.9 \pm 0.05$ \\
\hline
\end{tabular}

WHC, water holding capacity; MC, moisture content; wb, wet basis; FAS, free air space.

Mean \pm standard error, $\mathrm{n}=3$.

${ }^{1} \mathrm{BS}$, beef cattle manure and sawdust mixture.

${ }^{2} \mathrm{BR}$, beef cattle manure and rice hull mixture.

was produced per gram of oxygen consumed by microbes during composting. Energy generated during composting can be predicted based on oxygen uptake data acquired from a respiration test. The energy production potential of BS and BR under optimum moisture condition were $179 \mathrm{~J} / \mathrm{g}$ VS. $d$ and $452 \mathrm{~J} / \mathrm{g}$ VS. $d$ on a wet basis, respectively (Table $3)$.

\section{CONCLUSION}

Understanding of the optimum moisture content of bedding and beef manure mixtures collected from bedded pack barn enables better composting process control. The optimum moisture content of beef cattle manure and sawdust mixtures and beef cattle manure and rice hull mixtures were $70 \%$ and $57 \%$ on a wet basis, respectively. The optimum moisture contents of both beef manure mixtures were observed to be the near saturated state. Though their optimum moisture contents were near a saturated condition, FAS levels were high enough to maintain aerobic conditions. In future studies, field verification of the influence of optimum moisture content determined through respiration test on final compost quality is needed. Also, bio-decomposition and heat release performance of beef manure and bedding material mixtures at optimum moisture content should be investigated further.

Table 3. Energy generated through biodegradation of bedding materials and beef manure mixtures

\begin{tabular}{lrrrr}
\hline \% of WHC & \multicolumn{1}{c}{ Sawdust } & \multicolumn{1}{c}{ Rice hull } & \multicolumn{1}{c}{ BS $^{1}$} & \multicolumn{1}{c}{ BR $^{2}$} \\
\hline 30 & $4.06 \pm 0.11$ & $5.86 \pm 0.16$ & $21.58 \pm 0.03$ & $50.63 \pm 0.29$ \\
45 & $20.87 \pm 0.00$ & $62.68 \pm 0.15$ & $64.79 \pm 0.07$ & $280.51 \pm 0.73$ \\
60 & $24.59 \pm 0.08$ & $79.92 \pm 0.03$ & $75.78 \pm 0.13$ & $353.38 \pm 0.05$ \\
75 & $47.87 \pm 0.13$ & $101.05 \pm 0.22$ & $118.72 \pm 0.11$ & $452.37 \pm 0.58$ \\
90 & $42.64 \pm 0.04$ & $105.39 \pm 0.07$ & $179.41 \pm 0.27$ & $321.95 \pm 0.73$ \\
98 & $25.44 \pm 0.14$ & $106.52 \pm 0.22$ & $131.76 \pm 0.75$ & $308.36 \pm 1.39$ \\
\hline
\end{tabular}

WHC, water holding capacity; VS, volatile solids.

Mean \pm standard error, $\mathrm{n}=3, \mathrm{~J} / \mathrm{g}$ VS d

${ }^{1} \mathrm{BS}$, beef cattle manure and sawdust mixture.

${ }^{2} \mathrm{BR}$, beef cattle manure and rice hull mixture. 


\section{CONFLICT OF INTEREST}

We certify that there is no conflict of interest with any financial organization regarding the material discussed in the manuscript.

\section{ACKNOWLEDGMENTS}

This study was supported by the Rural Development Administration (Project No. PJ009805) Republic of Korea.

\section{REFERENCES}

Adani, F., C. Ubbiali, and P. Generini. 2006. The determination of biological stability of composts using the dynamic respiration index: the results of experience after two years. Waste Manag. 26:41-48

Ahn, H. K., J. H. Kim, J. H. Kwag, K. H. Jeong, D. Y. Choi, and Y. H. Yoo. 2011. Sustainable animal waste management and utilization in Korean livestock farms. "Sustainable research management of livestock and poultry wastes for Asian smallscale farmers" International seminar. Food and Fertilizer Technology Center, Ho Chi Minh, Vietnam. 41-46.

Ahn, H. K., T. L. Richard, and T. D. Glanville. 2008a. Laboratory determination of compost physical parameters for modeling of airflow characteristics. Waste Manag. 28:660-670.

Ahn, H. K., T. L. Richard, and T. D. Glanville. 2008b. Optimum moisture levels for biodegradation of mortality composting envelope materials. Waste Manag. 28:1411-1416.

Ahn, H. K., T. J. Saure, T. L. Richard, and T. D. Glanville. 2009. Determination of thermal properties of composting bulking materials. Bioresour. Techonol. 100:3974-3981.

Barrena-Gómez, R. B., F. V. Vazquez Lima, M. G. Bolasell, T. Gea, and A. S. Sanchez-Ferrer. 2005. Respirometric assays at fixed and process temperatures to monitor composting process. Bioresour. Technol. 96:1153-1159.

Barrena-Gómez, R., F. Vázquez-Lima, and F. Sánchez-Ferrer. 2006. The use of respiration indices in the composting process: A review. Waste Manag. Res. 24:37-47.

Das, K. and H. M. Keener. 1997. Moisture effect on compaction and permeability in composts. J. Environ. Eng. 123:275-281.

de Bertoldi, M., G. Vallini, and A. Pera. 1983. The biology of composting: A review. Waste Manag. Res. 1:157-176.

Gea, T., R. Barrena, A. Artola, and A. Sánchez. 2004. Monitoring the biological activity of the composting process: oxygen uptake rate (OUR), respirometric index (RI), and respiratory quotient (RQ). Biotechnol. Bioeng. 88:520-527.

Glanville, T. D., H. K. Ahn, T. L. Richard, J. D. Harmon, D. L. Reynolds, and S. Akinc. 2013. Effect of envelope material on biosecurity during emergency bovine mortality composting. Bioresour. Technol. 130:543-551.

Haug, R. T. 1993. Process kinetics and product stability. In: The Practical Handbook of Compost Engineering. Lewis Publishers, Boca Raton, FL, USA. 335-383.

Jeris, J. S. and R. W. Regan. 1973. Controlling environmental parameters for optimum composting. Part II. Compost Sci. 14:8-15.

Komilis, D. and D. Kanellos. 2012. A modified dynamic respiration test to assess compost stability: Effect of sample size and air flowrate. Bioresour. Technol. 117:300-309.

Komilis, D., I. Kontou, and S. Ntougias. 2011. A modified static respiration assay and its relationship with an enzymatic test to assess compost stability and maturity. Bioresour. Technol. 102:5863-5872.

Komilis, D. P. and I. S. Tziouvaras. 2009. A statistical analysis to assess the maturity and stability of six composts. Waste Manag. 29:1504-1513.

Külcü, R. and O. Yaldiz. 2014. The composting of agricultural wastes and the new parameter for the assessment of the process. Ecol. Eng. 69:220-225.

Liang, C., K. C. Das, and R. W. McClendon. 2003. The influence of temperature and moisture contents regimes on the aerobic microbial activity of a biosolids composting blend. Bioresour. Technol. 86:131-137.

Li, X. J., R. H. Zhang, and Y. Z. Pang. 2008. Characteristics of dairy manure composting with rice straw. Bioresour. Technol. 99:359-367.

Mabuhay, J. A., N. Nakagoshi, and T. Horikoshi. 2003. Microbial biomass and abundance after forest fire in pine forests in Japan. Ecol. Res. 18:431-441.

Murwira, H. K., H. Kirchmann, and M. J. Swift. 1990. The effect of moisture on the decomposition rate of cattle manure. Plant Soil 122:197-199.

Okutani, T. 2009. Utilization of silica in rice hulls as raw materials for silicon semiconductors. Met. Mater. Miner. 19:51-59.

Ponsá, S., T. Gea, and A. Sánchez. 2010. The effect of storage and mechanical pretreatment on the biological stability of municipal solid wastes. Waste Manag. 30:441-445.

Ponsá, S., E. Pagans, and A. Sánchez. 2009. Composting of dewatered wastewater sludge with various ratios of pruning waste used as a bulking agent and monitored by respirometer. Biosyst. Eng. 102:433-443.

Rahman, S. 1995. Food Properties Handbook. CRC Press, Boca Raton, FL, USA.

Richard, T. L., H. V. M. Hamelers, A. H. M. Veeken, and T. Silva. 2002. Moisture relationships in composting processes. Compost Sci. Util. 10:286-302.

Ruggieri, L., T. Gea, M. Mompeo, T. Sayara, and A. Sánchez. 2008. Performance of different systems for the composting of the source-selected organic fraction of municipal solid waste. Biosyst. Eng. 101:78-86.

Sadaka, S. S., T. L. Richard, T. D. Loecke, and M. Liebman. 2004. Determination of compost respiration rates using pressure sensors. ASAE Paper No. 047019. Ottawa, Canada.

Tamura, T. and T. Osada. 2006. Effect of moisture control in piletype composting of dairy manure by adding wheat straw on greenhouse gas emission. Int. Congr. Ser. 1293:311-314.

Thompson, W. H., P. D. Millner, M. E. Watson, and P. B. Leege. 2002. Test Methods for the Examination of Composting and Compost (TMECC). USCC (United States Composting Council), Holbrook, NY, USA.

Tremier, A., A. de Guardia, C. Massiani, E. Paul, and J. L. Martel. 2005. A respirometric method for characterizing the organic composition and biodegradation kinetics and the temperature influence on the biodegradation kinetics, for a mixture of sludge and bulking agent to be co-composted. Bioresour. Technol. 96:169-180. 
USCC. 2002. TMECC 4.11-A: Test methods for the examination of composting and compost. US Composting Council. Ronkonkonma, NY, USA.

van Ginkel, C. T., P. A. C. Raats, and I. A. van Haneghem. 1999. Bulk density and porosity distributions in a compost pile. Netherlands J. Agric. Sci. 47:105-121.
Wagland, S. T., S. F. Tyrrel, A. R. Godley, and R. Smith. 2009. Test methods to aid in the evaluation of the diversion of biodegradable municipal solid waste (BMW) from landfill. Waste Manag. 29:1218-1226.

Zhu, N. W. 2006. Composting of high moisture content swine manure with corncob in a pilot-scale aerated static bin system. Bioresour. Technol. 97:1870-1875. 